\title{
ANALISIS PENINGKATAN TINGKAT PENGUJIAN ULANG DALAM PROSES UJI LABORATORIUM PRODUK TEKSTIL MENGGUNAKAN METODE FMEA
}

\author{
Afifulloh Afifulloh, Hasbullah Hasbullah
}

Magister Teknik Industri, Universitas Mercu Buana, Indonesia

\begin{abstract}
Third-party laboratories are laboratories that provide analytical services as quality control of an item to be marketed. In its activities, sometimes the results of the analysis produced by the laboratory are not all acceptable because there are analysis results that do not meet the test quality specifications. The purpose of this study is to improve the defect rate on the test results using $Q C$ tools and FMEA methods. The findings in this study identify the main root causes are the errors of analysts when doing testing, there are no standard procedures for instrument maintenance, and lack of supervision. The proposed improvements given are personnel training, working instruction for instrument maintenance, logbook for record the activity and tighter supervision. After repairs, the defect rate in the test results can be reduced from $5.72 \%$ to $1.02 \%$.
\end{abstract}

Keyword: FMEA, Laboratory, Re-testing, Textiles.

\section{Pendahuluan}

Kesadaran konsumen akan produk yang berkualitas tumbuh dari waktu ke waktu. Ini membuat perusahaan-perusahaan di bidang manufaktur dituntut untuk meningkatkan kualitas produk agar dapat mempertahankan persaingan dengan perusahaan lain. Efisiensi dan kualitas barang dan jasa adalah salah satu kunci utama bagi perusahaan untuk bertahan hidup. Sama dengan perusahaan manufaktur yang menghasilkan barang, perusahaan jasa juga dipaksa untuk menghasilkan produk layanan yang berkualitas. Ketepatan waktu dalam menyediakan produk layanan kepada pelanggan diperlukan untuk menjaga kelangsungan bisnis. Saat ini perkembangan sektor industri jasa cukup baik. Industri jasa seperti transportasi, pengiriman, layanan konsultasi serta layanan analisis dan inspeksi sedang berkembang di Indonesia. Industri jasa memiliki prospek yang baik, sehingga peluang ini harus dimanfaatkan sebaik mungkin oleh para pemain industri jasa dengan meningkatkan kinerja sehingga lebih cepat dan lebih tepat sehingga perusahaan dapat bertahan dalam persaingan bisnis, data yang dikeluarkan oleh kementerian industri dalam analisis pengembangan industri pada 
edisi kedua 2018, pada kuartal pertama 2018 industri sektor jasa perusahaan naik $8,04 \%$ tahun (sumber: Kementerian Perindustrian).

Salah satu produk layanan yang dibutuhkan oleh pelanggan adalah layanan pengujian laboratorium. Layanan pengujian laboratorium yang diperlukan adalah untuk mengesahkan suatu produk. Laboratorium independen (laboratorium pihak ketiga) adalah laboratorium yang tidak berafiliasi dengan perusahaan tempat produk diproduksi. Laboratorium ini bebas tanpa paksaan dari pihak mana pun sehingga hasil analisis yang dikeluarkan tidak terganggu oleh permintaan pelanggan. Ini tertera dalam salah satu klausul ISO 17025: 2017 tentang ketidakberpihakan. Menurut ISO 17025: 2017 klausul 4.1.1 dan klausul 4.1.2, kegiatan laboratorium harus dilakukan secara tidak memihak dan terstruktur dan dikelola untuk mempertahankan ketidakberpihakan.

Pada perusahaan manufaktur yang menghasilkan barang, mereka memiliki masalah yang berkaitan dengan bekerja kembali. Re-work adalah proses dimana barang dibuat untuk memenuhi persyaratan yang ditentukan oleh penyelesaian atau koreksi [1]. Sama seperti di perusahaan manufaktur, pengujian ulang adalah salah satu pemborosan dalam kegiatan laboratorium yang harus dihilangkan. Pengujian ulang biasanya dilakukan untuk memastikan hasil analisis yang telah diperoleh valid. Beberapa faktor yang memerlukan pengujian berulang, salah satunya adalah kontrol kualitas dari langkah pengujian tidak sesuai dengan spesifikasi sehingga hasil analisis diragukan dan masih banyak faktor lain yang menyebabkan hasil analisis harus diuji ulang. Menjadi penting untuk diteliti tentang pengujian ulang laboratorium uji yang merupakan salah satu limbah. Di perusahaan jasa yang akan diteliti oleh penulis, rata-rata ada sekitar 35.000 tes tahunan dengan rata-rata tes ulang 4-5\%. Salah satu metode yang dapat digunakan untuk mengurangi angka pengujian ulang yang tidak perlu adalah FMEA (Failure Mode Effect Analysis).

\section{Tinjauan Pustaka}

Pengujian di laboratorium sangat rentan terhadap kesalahan pengujian. Ini karena pekerjaan di laboratorium adalah pekerjaan lintas departemen [7]. Kesalahan pengujian akan menyebabkan pengujian ulang yang membutuhkan biaya produksi tambahan. Beberapa penelitian sebelumnya juga memiliki masalah dengan pengujian ulang. Dalam jurnal yang ditulis oleh Giuseppe Lippi, et.al. ada $22 \%$ pengujian ulang yang terdeteksi dalam sistem. dari deteksi ini, $16,70 \%$ pengujian ulang tidak diizinkan. Dari pengurangan pengujian ulang, penghematan biaya sebesar 12,8\% dicatat dari total biaya pengujian selama periode pengamatan [2]. Dalam jurnalnya, Hawkins menyimpulkan hasil penelitiannya bahwa jumlah pengujian ulang yang tidak perlu adalah $2 \%$ dari total uji atau lebih dari 70 uji per hari [3]. Sementara itu, penelitian yang dilakukan oleh Huissoon dan Carlton, menyimpulkan bahwa ada $7,3 \%$ pengujian ulang yang tidak diperlukan dari total beban kerja dengan biaya $£ 13.000$ [4]. Selain menimbulkan biaya tambahan, pengujian ulang juga menyebabkan keterlambatan Turn Around Time (TAT). TAT digunakan sebagai indikator untuk efisiensi laboratorium [5]. Konsumen jasa pengujian sangat 
membutuhkan ketepatan waktu kerja dan juga hasil yang valid karena hasil laboratorium sangat penting untuk digunakan sebagai dasar pengambilan keputusan.

Pengujian ulang akan menyebabkan biaya baru yang seharusnya tidak dikeluarkan. Ini membuat inefisiensi dalam proses kerja. Limbah terjadi dalam hal biaya pengujian ulang dan tenaga kerja yang dikeluarkan oleh pekerja. Padahal, untuk mengejar ketinggalan terkadang butuh kerja lembur. Kemungkinan penyebab pengerjaan ulang dikategorikan secara luas termasuk (1) perubahan ruang lingkup; (2) desain / dokumentasi yang salah; (3) kurangnya sistem manajemen mutu; dan (4) pengerjaan yang buruk [6]. Sejumlah faktor utama termasuk (1) kesalahan interpretasi gambar dan spesifikasi; (2) penggunaan spesifikasi yang diganti dalam rantai pasokan; (3) komunikasi yang buruk atau tidak tepat; (4) kurangnya koordinasi rantai pasokan; (5) tingkat pelatihan dan keterampilan yang buruk; dan pengawasan yang tidak memadai [7]. Sumber kesalahan terbesar yang diidentifikasi adalah kesalahan karena kurangnya pelatihan, kompetensi rendah, dan kepedulian terhadap pekerjaan [8].

Kesalahan pengujian dapat dikurangi menggunakan metode Failure Mode and Effects Analysis (FMEA). Metode ini digunakan untuk banyak studi sebagai metode yang efektif untuk manufaktur otomotif. FMEA diperkenalkan di industri dirgantara pada 1960-an, dan telah diterapkan di industri kesehatan untuk pengembangan sistem kritis dalam pembuatan obat dan pencegahan kesalahan pengobatan di rumah sakit [9] [10]. Teknik FMEA dapat diterapkan pada proses laboratorium [11]. Setiap langkah kerja FMEA dievaluasi untuk mengidentifikasi semua faktor risiko yang mungkin terjadi dan kemudian diambil langkah korektif. Metode ini juga cocok untuk digunakan di bagian lain untuk memberikan layanan yang lebih baik kepada pelanggan [12]. Metode FMEA digunakan untuk mengatasi masalah proses, sistem dan produk serta mencegahnya. Fokus metode ini adalah mengurangi risiko sehingga perusahaan dapat meningkatkan produktivitas dan kepuasan pelanggan. FMEA bisa digunakan dalam pengembangan produk atau desain produk, tetapi metode FMEA masih memberikan manfaat jika digunakan dalam suatu proses atau produk [13]. FMEA memberikan alat untuk mencari masalah utama dengan cara pemberian skor. FMEA membutuhkan beberapa parameter yang digunakan untuk menentukan tingkat keparahan, kemunculan dan kemampuan mendeteksi. Dari ketiga faktor ini, nilai prioritas risiko (RPN) kemudian ditentukan. Berdasarkan nilai RPN, saran untuk perbaikan dari sumber utama masalah diusulkan untuk mengurangi risiko kesalahan yang akan terjadi dan menyebabkan kerugian bagi perusahaan dalam kualitas, keuangan dan waktu [14]. Metode FMEA dipilih karena dapat digunakan untuk memprioritaskan risiko dan mendorong efektivitas kegiatan pengendalian [15].

\section{Metodologi}

Penelitian ini merupakan studi kasus di salah satu laboratorium pengujian tekstil di Indonesia. Pengumpulan data dilakukan dengan observasi langsung, observasi rekaman, dan Focus Group Discussion (FGD). 2 pengawas laboratorium dan 1 analis 
senior dilibatkan dalam penelitian ini sebagai expert. Penelitian dilakukan dengan memeriksa alur kerja di laboratorium, lalu memeriksa data dari pengujian total, pengujian ulang, dan sumber kesalahan pengujian ulang. Parameter uji yang memiliki tingkat pengujian ulang tertinggi dijadikan prioritas dengan peningkatan. Mode yang ditentukan diberikan dan diberi peringkat dengan nilai 1-10 dengan tingkat keparahan (S), frekuensi kemunculan (O) dan probabilitas kegagalan yang tidak dapat diubah (D). kemudian, Nomor Prioritas Risiko ditentukan. Risk Priority Number (RPN) ditemukan dengan penggandaan tingkat keparahan, kejadian dan nilai deteksi $(\mathrm{RPN}=\mathrm{S} \times \mathrm{O} \times \mathrm{D})$. Semakin tinggi nilai RPN, semakin tinggi pula kebutuhan untuk mengambil tindakan [9].

\section{Hasil dan Pembahasan}

Data jumlah dikumpulkan berdasarkan banyaknya pengujian contoh uji per-bulan perparameter selama tahun 2018. Dari data 3 tahun terakhir, biasanya puncak dari load analisis terjadi 2 bulan sebelum hari raya idul fitri dikarenakan pabrik tekstil di Indonesia mengejar produksi untuk persiapan liburan hari raya Idul fitri.

\section{Total Pengujian Tahun 2018}

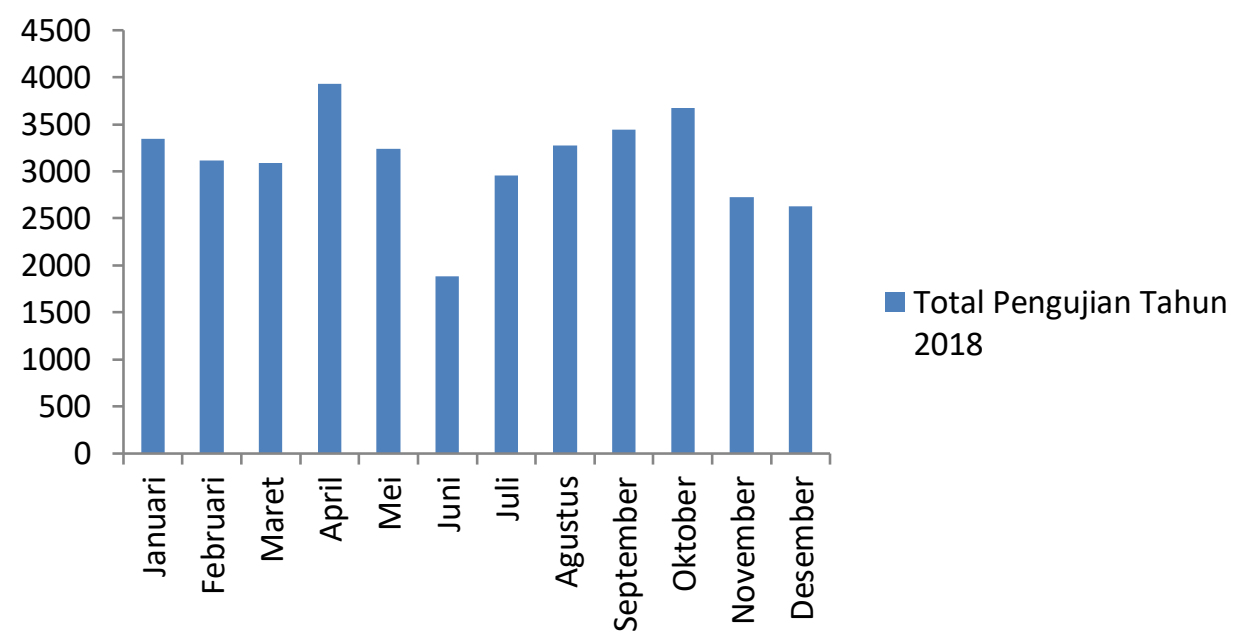

Gambar 1. Diagram Total Testing 2018

Hasil pengujian ulang berdasarkan parameter uji diproses dan difokuskan pada parameter uji yang terjadi sebagian besar pengujian ulang menggunakan diagram Pareto sehingga memudahkan untuk menganalisis akar masalah pada masalah terbesar yang terjadi. yang ditunjukkan di bawah ini adalah parameter pengujian yang memiliki masalah pengujian ulang. 
Tabel 1. Total pengujian dan Pengujian Ulang 2018

\begin{tabular}{|c|l|r|r|r|}
\hline No. & \multicolumn{1}{|c|}{ Parameter Uji } & Jumlah Pengujian & $\begin{array}{c}\text { Jumlah } \\
\text { Pengujian Ulang }\end{array}$ & $\begin{array}{c}\text { Pengujian } \\
\text { Ulang (\%) }\end{array}$ \\
\hline 1 & DMFu & 114 & 0 & 0.00 \\
\hline 2 & Organotin & 69 & 0 & 0.00 \\
\hline 3 & PBB-PBDE & 1317 & 0 & 0.00 \\
\hline 4 & Phthalates & 3489 & 57 & 1.63 \\
\hline 5 & Azo dyes & 4024 & 63 & 1.57 \\
\hline 6 & PFOS \& PFOA & 129 & 0 & 0.00 \\
\hline 7 & Disperse dyes & 189 & 5 & 2.65 \\
\hline 9 & APEO (NPEO, OPEO) & 733 & 16 & 2.18 \\
\hline 10 & Bisphenol A & 15 & 1 & 6.67 \\
\hline 12 & Heavy Metal & 25782 & 1474 & 5.72 \\
\hline 13 & Chromium VI & 1440 & 15 & 1.04 \\
\hline Total & & 37301 & 1631 & 4.37 \\
\hline
\end{tabular}

(Sumber: data internal IUS)

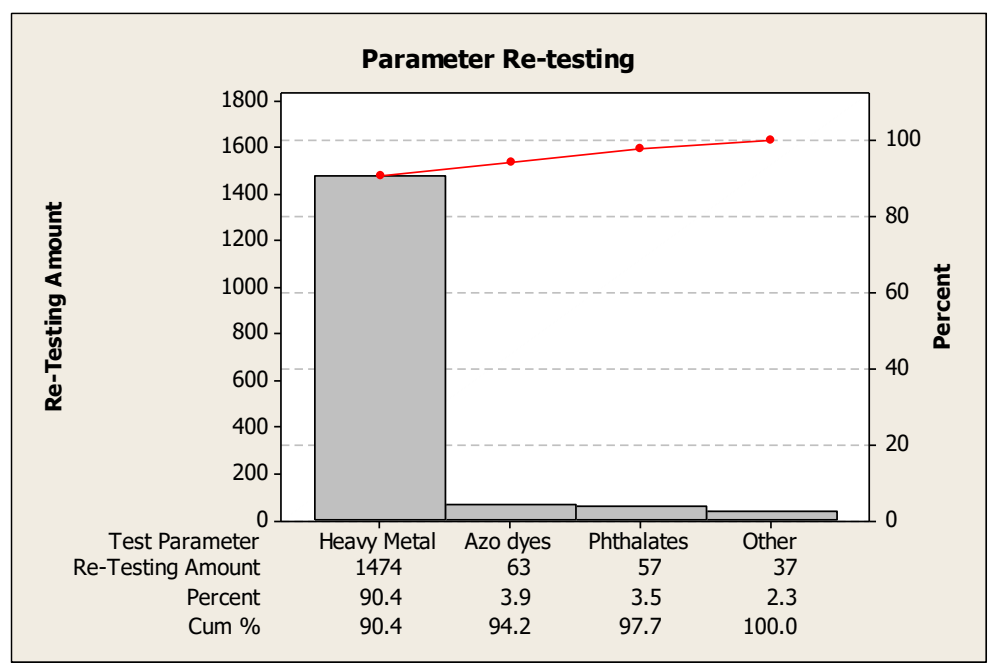

Gambar 2. Pareto Chart Parameter Pengujian Ulang

Kemudian, dari data pengujian ulang untuk parameter logam berat, tim laboratorium melakukan breakdown data pengujian ulang berdasarkan kesalahan yang menyebabkan pengujian ulang terjadi sehingga sumber terbesar pengujian ulang dapat ditemukan. Data disajikan dalam gambar di bawah ini. 


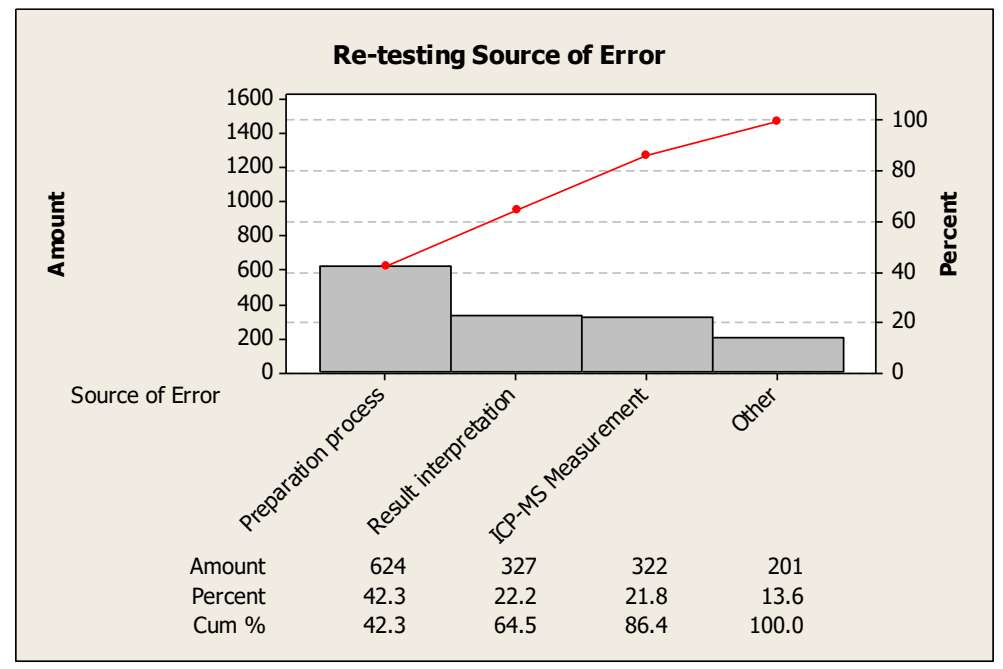

Picture 3. Pareto Chart Sumber Kesalahan Pengujian Ulang

Dari diagram Pareto di atas, dapat disimpulkan bahwa ada tiga penyebab utama pengujian ulang pada pengujian logam berat, yaitu kesalahan dalam proses persiapan, proses pengukuran ICP-MS, dan proses interpretasi hasil. Untuk penyebab lain seperti kesalahan penyortiran komponen, tidak berkontribusi signifikan sebagai penyebab pengujian ulang. Maka, penyebab ini dapat diabaikan. Sebenarnya, logam berat dalam produk tekstil dapat terkontaminasi atau sengaja ditambahkan. Alat bantu pembuatan tekstil seperti pewarna, cat, sablon, tinta cetak sering menggunakan logam berat untuk membentuk pigmen. Analisis logam berat dilakukan dengan menghancurkan sampel uji menggunakan asam pekat dengan suhu tinggi. Solusi sampel dianalisis menggunakan ICP MS. Mengikuti analisis diagram alir parameter logam berat. 


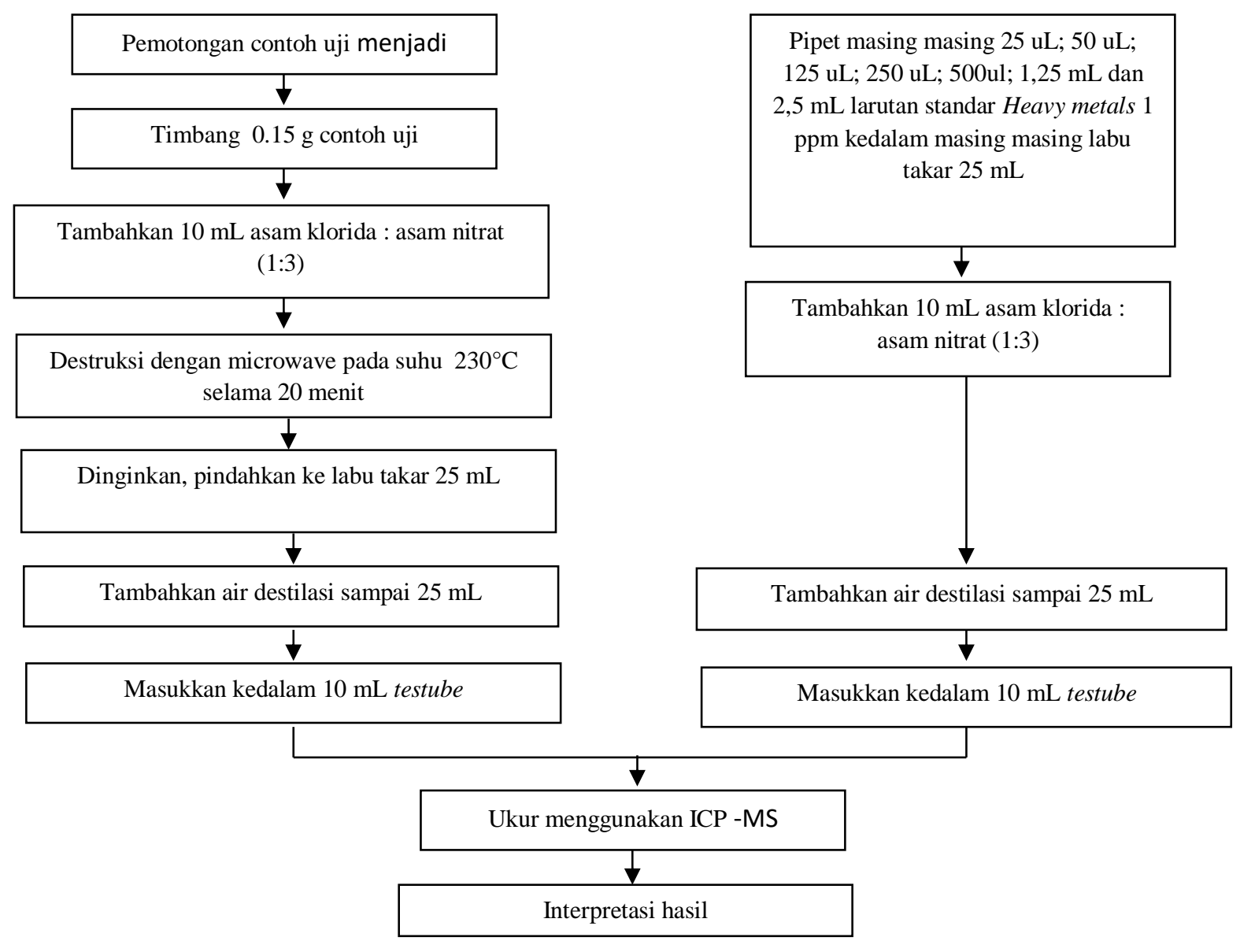

Gambar 4. Diagram Alir Proses Pengujian Heavy Metal

Focus Group Discussion (FGD) dilakukan oleh supervisor dan analis senior untuk menentukan nilai Severity, Occurrence and Detection (SOD) dari masing-masing masalah akar dan selanjutnya ditetapkan nilai RPN. Dari nilai RPN, prioritas tindakan korektif yang akan diambil ditentukan berdasarkan nilai RPN tertinggi. Dari nilai RPN, ditentukan prioritas tindakan perbaikan yang harus dilakukan yang diambil berdasarkan nilai RPN tertinggi. Penilaian Severity, Occurrence dan Detection diberikan dengan skala 1 - 10 dimana semakin besar nilainya akan semakin beresiko. Pelaksanaan rencana perbaikan dilakukan untuk mode kegagalan yang mempunyai RPN diatas 200. Berikut adalah tabel FMEA Proses Pengujian Heavy Metal. 
Tabel 2. Failure Mode Effect Analysis (FMEA) Proses Pengujian Heavy Metal

\begin{tabular}{|c|c|c|c|c|c|c|c|c|}
\hline Proses & $\begin{array}{l}\text { Sumber } \\
\text { kegagalan }\end{array}$ & $\begin{array}{l}\text { Potensi mode } \\
\text { kegagalan }\end{array}$ & $\begin{array}{l}\text { Potensi efek dari } \\
\text { kegagalan }\end{array}$ & 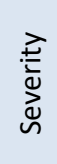 & 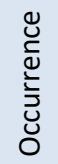 & 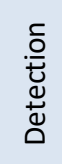 & RPN & Rekomendasi \\
\hline \multirow[t]{9}{*}{$\begin{array}{l}\text { Preparasi } \\
\text { Contoh Uji }\end{array}$} & $\begin{array}{l}\text { Pemotongan } \\
\text { contoh uji } \\
\text { menjadi lebih } \\
\text { kecil }\end{array}$ & $\begin{array}{l}\text { Pemotongan sampel } \\
\text { uji lebih besar dari } 1 \\
\mathrm{~mm} 2\end{array}$ & $\begin{array}{l}\text { Contoh uji sulit larut } \\
\text { sempurna pada saat } \\
\text { tahap digestion. }\end{array}$ & 3 & 3 & 1 & 9 & $\begin{array}{l}\text { Analis harus } \\
\text { memeperhatikan contoh } \\
\text { uji apakah sudah sesuai } \\
\text { dengan kriteria atau } \\
\text { belum }\end{array}$ \\
\hline & \multirow[t]{2}{*}{$\begin{array}{l}\text { penimbangan } \\
\text { contoh uji }\end{array}$} & $\begin{array}{l}\text { Contoh uji tercecer / } \\
\text { tidak masuk semua } \\
\text { kedalam vessel }\end{array}$ & $\begin{array}{l}\text { Nilai konsentasi heavy } \\
\text { metal lebih kecil dari } \\
\text { seharusnya. }\end{array}$ & 7 & 1 & 1 & 7 & $\begin{array}{l}\text { Mengggunakan spatula } \\
\text { kecil untuk menimbang. }\end{array}$ \\
\hline & & Tertukar contoh uji & hasil analisis salah & 7 & 1 & 7 & 49 & $\begin{array}{l}\text { Melakukan pelabelan } \\
\text { pada vessel. }\end{array}$ \\
\hline & $\begin{array}{l}\text { Penambahan } 10 \\
\text { mL asam klorida: } \\
\text { asam nitrat }(1: 3)\end{array}$ & $\begin{array}{l}\text { Larutan campuran } \\
\text { asam klorida dan } \\
\text { asam nitrat tercecer / } \\
\text { tidak masuk semua } \\
\text { kedalam vessel }\end{array}$ & $\begin{array}{l}\text { efektifitas digestion } \\
\text { berkurang }\end{array}$ & 7 & 1 & 1 & 7 & $\begin{array}{l}\text { Analis harus hati-hati } \\
\text { dalam memasukkan } \\
\text { larutan campuran asam } \\
\text { tersebut menggunakan } \\
\text { pipet. }\end{array}$ \\
\hline & \multirow[t]{2}{*}{$\begin{array}{l}\text { Destruksi dengan } \\
\text { microwave pada } \\
\text { suhu } 230^{\circ} \mathrm{C} \\
\text { selama } 20 \text { menit }\end{array}$} & $\begin{array}{l}\text { pengoperasian alat } \\
\text { yang tidak benar }\end{array}$ & alat menjadi rusak & 9 & 1 & 1 & 9 & $\begin{array}{l}\text { 1. Membuat IK untuk } \\
\text { pengoperasian alat } \\
\text { microwave digestion. } \\
\text { 2. Pelatihan untuk analis } \\
\text { baru. }\end{array}$ \\
\hline & & $\begin{array}{l}\text { Contoh uji tidak } \\
\text { terdestruksi } \\
\text { sempurna }\end{array}$ & $\begin{array}{l}\text { Nilai konsentasi } \\
\text { contoh uji heavy } \\
\text { metal lebih kecil dari } \\
\text { seharusnya. }\end{array}$ & 7 & 3 & 3 & 63 & $\begin{array}{l}\text { 1. Memastikan potongan } \\
\text { contoh uji }<1 \mathrm{~mm} 2 \text { pada } \\
\text { saat penimbangan } \\
\text { 2. Memastikan hasil } \\
\text { digest sempurna. }\end{array}$ \\
\hline & $\begin{array}{l}\text { Didinginkan dan } \\
\text { dipindahkan ke } \\
\text { labu takar } 25 \mathrm{~mL}\end{array}$ & $\begin{array}{l}\text { Larutan contoh uji } \\
\text { tercecer / tidak } \\
\text { masuk semua } \\
\text { kedalam vessel }\end{array}$ & $\begin{array}{l}\text { Nilai konsentasi } \\
\text { contoh uji heavy } \\
\text { metal lebih kecil dari } \\
\text { seharusnya. } \\
\text { Nilai konsentasi }\end{array}$ & 7 & 2 & 1 & 14 & $\begin{array}{l}\text { Menggunakan bantuan } \\
\text { corong untuk } \\
\text { memasukkan larutan } \\
\text { contoh uji. }\end{array}$ \\
\hline & $\begin{array}{l}\text { Tambahkan air } \\
\text { destilasi sampai } \\
25 \mathrm{~mL} \text {, di } \\
\text { homogenkan }\end{array}$ & $\begin{array}{l}\text { larutan contoh uji } \\
\text { lupa dihomogenkan }\end{array}$ & $\begin{array}{l}\text { contoh uji heavy } \\
\text { metal lebih kecil / } \\
\text { besar dari } \\
\text { seharusnya. }\end{array}$ & 8 & 1 & 7 & 56 & $\begin{array}{l}\text { Memastikan kompetensi } \\
\text { analis sebelum } \\
\text { melakukan analisis. }\end{array}$ \\
\hline & $\begin{array}{l}\text { Masukkan } \\
\text { kedalam test tube } \\
10 \mathrm{~mL}\end{array}$ & $\begin{array}{l}\text { Test tube } \\
\text { terkontaminasi }\end{array}$ & Hasil analisis salah & 7 & 1 & 10 & 70 & $\begin{array}{l}\text { Melakukan pelabelan } \\
\text { pada test tube. }\end{array}$ \\
\hline
\end{tabular}




\begin{tabular}{|c|c|c|c|c|c|c|c|c|}
\hline Proses & $\begin{array}{l}\text { Sumber } \\
\text { kegagalan }\end{array}$ & $\begin{array}{l}\text { Potensi mode } \\
\text { kegagalan }\end{array}$ & $\begin{array}{l}\text { Potensi efek dari } \\
\text { kegagalan }\end{array}$ & 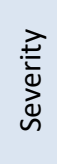 & 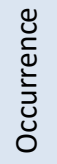 & 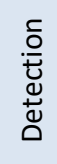 & RPN & Rekomendasi \\
\hline \multirow[t]{5}{*}{$\begin{array}{l}\text { Preparasi } \\
\text { Contoh Uji }\end{array}$} & $\begin{array}{l}\text { Memipet masing } \\
\text { masing } 25 \mathrm{uL} ; 50 \\
\mathrm{uL} ; 125 \mathrm{uL} ; 250 \\
\mathrm{uL} ; 500 \mathrm{ul} ; 1,25 \mathrm{~mL} \\
\text { dan } 2,5 \mathrm{~mL} \\
\text { larutan standar } \\
\text { Heavy metals } 1 \\
\text { ppm kedalam } \\
\text { masing masing } \\
\text { labu takar } 25 \mathrm{~mL}\end{array}$ & $\begin{array}{l}\text { Salah dalam volume } \\
\text { pemipetan }\end{array}$ & Hasil analisis salah & 8 & 5 & 7 & 280 & $\begin{array}{l}\text { 1. Memastikan } \\
\text { kompetensi analis dalam } \\
\text { melakukan pemipetan. } \\
\text { 2. Membuat logbook } \\
\text { pembuatan standar untuk } \\
\text { memastikan volume } \\
\text { pemipetan. }\end{array}$ \\
\hline & & $\begin{array}{l}\text { Larutan standar } \\
\text { tertukar }\end{array}$ & Hasil analisis salah & 5 & 1 & 7 & 35 & $\begin{array}{l}\text { Melakukan pelabelan } \\
\text { pada labu takar. }\end{array}$ \\
\hline & $\begin{array}{l}\text { Menambahkan } 10 \\
\mathrm{~mL} \text { asam klorida : } \\
\text { asam nitrat (1:3) }\end{array}$ & $\begin{array}{l}10 \mathrm{~mL} \text { asam klorida : } \\
\text { asam nitrat (1:3) lupa } \\
\text { ditambahkan }\end{array}$ & $\begin{array}{l}\text { Berpengaruh pada } \\
\text { hasil analisis }\end{array}$ & 2 & 1 & 1 & 2 & $\begin{array}{l}\text { Analis harus hati-hati } \\
\text { dalam memasukkan } \\
\text { larutan campuran asam } \\
\text { tersebut menggunakan } \\
\text { pipet. }\end{array}$ \\
\hline & $\begin{array}{l}\text { Menambahkan air } \\
\text { destilasi sampai } \\
25 \mathrm{~mL} \text {, di } \\
\text { homogenkan }\end{array}$ & $\begin{array}{l}\text { larutan standar uji } \\
\text { lupa dihomogenkan }\end{array}$ & $\begin{array}{l}\text { Kurva kalibrasi tidak } \\
\text { bisa digunakan } \\
\text { sebagai perhitungan. }\end{array}$ & 8 & 1 & 7 & 56 & $\begin{array}{l}\text { Memastikan kompetensi } \\
\text { analis sebelum } \\
\text { melakukan analisis. }\end{array}$ \\
\hline & $\begin{array}{l}\text { Masukkan } \\
\text { kedalam test tube } \\
10 \mathrm{~mL}\end{array}$ & $\begin{array}{l}\text { Test tube } \\
\text { terkontaminasi }\end{array}$ & Hasil analisis salah & 7 & 1 & 10 & 70 & $\begin{array}{l}\text { Melakukan pelabelan } \\
\text { pada test tube. }\end{array}$ \\
\hline \multirow[t]{4}{*}{$\begin{array}{l}\text { Pengukuran } \\
\text { dengan } \\
\text { menggunak } \\
\text { an ICP-MS }\end{array}$} & $\begin{array}{l}\text { Warming-up } \\
\text { instrumen ICP MS } \\
\text { selama } 15 \text { menit }\end{array}$ & $\begin{array}{l}\text { Analis melakukan } \\
\text { shortcut pada langkah } \\
\text { warming-up }\end{array}$ & $\begin{array}{l}\text { Sinyal pembacaan } \\
\text { tidak stabil }\end{array}$ & 6 & 1 & 3 & 18 & $\begin{array}{l}\text { 1. Memastikan } \\
\text { kompetensi analis. } \\
\text { 2. Kontrol dari senior } \\
\text { analis }\end{array}$ \\
\hline & $\begin{array}{l}\text { Melakukan } \\
\text { pengecekan } \\
\text { kondisi instrumen }\end{array}$ & $\begin{array}{l}\text { Analis tidak } \\
\text { melakukan } \\
\text { pengecekan kondisi } \\
\text { instrumen dengan } \\
\text { benar }\end{array}$ & $\begin{array}{l}\text { sinyal pembacaan } \\
\text { internal standar, } \\
\text { contoh uji dan/atau } \\
\text { standar tidak stabil. }\end{array}$ & 6 & 7 & 6 & 252 & $\begin{array}{l}\text { 1. Memastikan } \\
\text { kompetensi analis. } \\
\text { 2. Membuat IK untuk } \\
\text { pengecekan kondisi } \\
\text { instrumen } \\
\text { 3. Membuat logbook } \\
\text { untuk pengecekan kondisi } \\
\text { instrumen } \\
\text { 4. Kontrol dari senior } \\
\text { analis }\end{array}$ \\
\hline & $\begin{array}{l}\text { Meletakkan } \\
\text { larutan kurva } \\
\text { kalibrasi dan } \\
\text { contoh uji pada } \\
\text { auto sampler }\end{array}$ & $\begin{array}{l}\text { Kesalahan } \\
\text { meletakkan urutan } \\
\text { tempat larutan } \\
\text { contoh uji / larutan } \\
\text { kurva kalibrasi. }\end{array}$ & Hasil analisis salah & 5 & 1 & 6 & 30 & $\begin{array}{l}\text { 1. Memastikan } \\
\text { kompetensi analis. } \\
\text { 2. Kontrol dari senior } \\
\text { analis }\end{array}$ \\
\hline & $\begin{array}{l}\text { Memprogram } \\
\text { instrument ICP- } \\
\text { MS }\end{array}$ & $\begin{array}{l}\text { Kesalahan } \\
\text { pemrograman letak } \\
\text { urutan larutan contoh } \\
\text { uji/larutan kurva } \\
\text { kalibrasi }\end{array}$ & Hasil analisis salah & 5 & 1 & 6 & 30 & $\begin{array}{l}\text { 1. Memastikan } \\
\text { kompetensi analis. } \\
\text { 2. Kontrol dari senior } \\
\text { analis }\end{array}$ \\
\hline
\end{tabular}




\begin{tabular}{|c|c|c|c|c|c|c|c|c|}
\hline Proses & $\begin{array}{l}\text { Sumber } \\
\text { kegagalan }\end{array}$ & $\begin{array}{l}\text { Potensi mode } \\
\text { kegagalan }\end{array}$ & $\begin{array}{l}\text { Potensi efek dari } \\
\text { kegagalan }\end{array}$ & 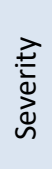 & 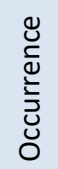 & 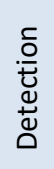 & RPN & Rekomendasi \\
\hline \multirow[t]{4}{*}{$\begin{array}{l}\text { Pengukura } \\
\text { n dengan } \\
\text { menggunak } \\
\text { an ICP-MS }\end{array}$} & $\begin{array}{l}\text { Memprogram } \\
\text { instrument ICP- } \\
\text { MS }\end{array}$ & $\begin{array}{l}\text { Kesalahan } \\
\text { pemrograman } \\
\text { metode analisa }\end{array}$ & Hasil analisis salah & 6 & 2 & 3 & 36 & $\begin{array}{l}\text { 1. Memastikan } \\
\text { kompetensi analis. } \\
\text { 2. Kontrol dari senior } \\
\text { analis }\end{array}$ \\
\hline & $\begin{array}{l}\text { Kurva kalibrasi di } \\
\text { running }\end{array}$ & $\begin{array}{l}\text { Tidak ada potensi } \\
\text { mode kegagalan }\end{array}$ & $\begin{array}{l}\text { Tidak ada potensi } \\
\text { efek dari kegagalan }\end{array}$ & 1 & 1 & 1 & 1 & Tidak ada rekomendasi \\
\hline & $\begin{array}{l}\text { Contoh uji di } \\
\text { running }\end{array}$ & $\begin{array}{l}\text { Tidak ada potensi } \\
\text { mode kegagalan }\end{array}$ & $\begin{array}{l}\text { Tidak ada potensi } \\
\text { efek dari kegagalan }\end{array}$ & 1 & 1 & 1 & 1 & Tidak ada rekomendasi \\
\hline & $\begin{array}{l}\text { Mematikan alat } \\
\text { instrument }\end{array}$ & $\begin{array}{l}\text { Kesalahan prosedur } \\
\text { dalam mematikan } \\
\text { alat instrumen }\end{array}$ & Alat instrumen rusak & 9 & 1 & 1 & 9 & $\begin{array}{l}\text { Memastikan kompetensi } \\
\text { analis }\end{array}$ \\
\hline \multirow[t]{6}{*}{$\begin{array}{l}\text { Interpretasi } \\
\text { hasil }\end{array}$} & $\begin{array}{l}\text { Pengecekan kurva } \\
\text { kalibrasi }\end{array}$ & $\begin{array}{l}\text { Kurva kalibrasi tidak } \\
\text { memiliki r lebih dari } \\
0.995\end{array}$ & Hasil uji tidak valid & 6 & 8 & 2 & 96 & $\begin{array}{l}\text { 1. Memastikan } \\
\text { kompetensi analis. } \\
\text { 2. Memastikan kondisi } \\
\text { alat instrumen baik }\end{array}$ \\
\hline & & $\begin{array}{l}\text { Adanya konsentrasi } \\
\text { larutan contoh uji } \\
\text { yang diluar rentang } \\
\text { kurva kalibrasi }\end{array}$ & Hasil uji tidak valid & 5 & 10 & 7 & 350 & $\begin{array}{l}\text { 1. Penggunaan hasil } \\
\text { screening XRF untuk } \\
\text { menentukan perkiraan } \\
\text { pengenceran larutan } \\
\text { contoh uji. } \\
\text { 2. Pelatihan analis untuk } \\
\text { perhitungan perkiraan } \\
\text { pengenceran. }\end{array}$ \\
\hline & $\begin{array}{l}\text { Pengecekan } \\
\text { blanko uji }\end{array}$ & $\begin{array}{l}\text { Adanya kontaminasi } \\
\text { dari blanko uji }\end{array}$ & Hasil uji tidak valid & 5 & 1 & 10 & 50 & $\begin{array}{l}\text { 1. Memastikan } \\
\text { kompetensi analis. } \\
\text { 2. Memastikan kondisi } \\
\text { alat instrumen baik. } \\
\text { 3. memastikan tidak ada } \\
\text { kontaminasi dari } \\
\text { peralatan preparasi }\end{array}$ \\
\hline & $\begin{array}{l}\text { Pengecekan } \\
\text { perolehan } \\
\text { kembali (\% } \\
\text { recovery) }\end{array}$ & $\begin{array}{l}\text { Hasil recovery tidak } \\
\text { diantara } 85-115 \%\end{array}$ & Hasil uji tidak valid & 8 & 1 & 10 & 80 & $\begin{array}{l}\text { 1. Memastikan } \\
\text { kompetensi analis. } \\
\text { 2. Memastikan kondisi } \\
\text { alat instrumen baik. } \\
\text { 3. memastikan } \\
\text { pembuatan larutan uji } \\
\text { recovery benar. }\end{array}$ \\
\hline & $\begin{array}{l}\text { Pengecekan } \\
\text { internal standar }\end{array}$ & $\begin{array}{l}\text { Hasil Internal standar } \\
\text { diantara } 80-120 \%\end{array}$ & Hasil uji tidak valid & 5 & 4 & 3 & 60 & $\begin{array}{l}\text { 1. Memastikan } \\
\text { kompetensi analis. } \\
\text { 2. Memastikan kondisi } \\
\text { alat instrumen baik. }\end{array}$ \\
\hline & $\begin{array}{l}\text { Kalkulasi hasil } \\
\text { pengukuran } \\
\text { instrumen ICP-MS }\end{array}$ & $\begin{array}{l}\text { kesalahan dalam } \\
\text { kalkulasi hasil }\end{array}$ & Hasil analisis salah & 4 & 1 & 3 & 12 & $\begin{array}{l}\text { 1. Memastikan } \\
\text { kompetensi senior analis } \\
\text { dalam kalkulasi. } \\
\text { 2. Senior Analis } \\
\text { memastikan rumus } \\
\text { perhitungan benar }\end{array}$ \\
\hline
\end{tabular}


Dari studi tim laboratorium tempat penelitian dilakukan, nilai RPN tertinggi adalah 350. Mode kegagalan adalah konsentrasi larutan sampel uji di luar kisaran kurva kalibrasi. Alasannya adalah analis tidak merujuk pada hasil screening untuk memperkirakan pengenceran yang harus dilakukan. Kemudian, nilai RPN tinggi berikutnya adalah mode kegagalan dalam membuat larutan standar kurva kalibrasi. Nilai RPN yang diperoleh adalah 280. Teknik memipet menjadi masalah utama yang menyebabkan kesalahan dalam mode kegagalan ini. Selain itu, dalam beberapa kasus ada kesalahan ketika mengambil volume larutan stok standar sehingga hasil kurva kalibrasi tidak linier. Mode kegagalan yang juga cukup tinggi adalah pengecekan kinerja instrumen ICP-MS sebelum digunakan untuk membaca solusi sampel uji tidak baik. Nilai RPN untuk mode kegagalan ini adalah 252. Mode kegagalan ini kemungkinan karena kompetensi analis dalam melakukan langkah-langkah kerja untuk memeriksa unjuk kerja alat kurang baik. Selain itu, instruksi kerja terkait dengan pengecekan instrumen ICP-MS belum dibuat.

Setelah mengevaluasi, rancangan tindakan korektif dibuat. Namun, tidak semua tindakan korektif yang diusulkan, diambil. Tindakan korektif yang diusulkan dilakukan hanya untuk mode kegagalan dengan nilai RPN lebih dari 200. Tindakan korektif yang diambil adalah memastikan kompetensi dengan memberikan pelatihan, menjadikan logbook sebagai pengontrol mandiri bagi analis dalam membuat kurva kalibrasi dan sebagai alat penelusuran. Selain itu, instruksi kerja perawatan dan pengoperasian instrumen harus dibuat. Data screening XRF dapat digunakan sebagai tindakan korektif. Data screening digunakan sebagai referensi untuk memperkirakan pengenceran larutan sampel uji. Estimasi yang akurat akan mengurangi jumlah pengukuran ulang pada alat instrumentasi ICP-MS

Tabel 3. Usulan Perbaikan untuk Menurunkan Angka Pengujian Ulang

\begin{tabular}{|c|c|c|c|c|}
\hline No. & Proses & Sumber kegagalan & $\begin{array}{l}\text { Potensi mode } \\
\text { kegagalan }\end{array}$ & usulan perbaikan \\
\hline 1 & $\begin{array}{l}\text { Preparasi } \\
\text { Contoh Uji }\end{array}$ & $\begin{array}{l}\text { Memipet masing } \\
\text { masing } 25 \mathrm{uL} ; 50 \mathrm{uL} ; \\
125 \mathrm{uL} ; 250 \mathrm{uL} ; 500 \mathrm{ul} ; \\
1,25 \mathrm{~mL} \text { dan } 2,5 \mathrm{~mL} \\
\text { larutan standar Heavy } \\
\text { metals } 1 \mathrm{ppm} \text { kedalam } \\
\text { masing masing labu } \\
\text { takar } 25 \mathrm{~mL}\end{array}$ & $\begin{array}{l}\text { Salah dalam } \\
\text { volume pemipetan }\end{array}$ & $\begin{array}{l}\text { 1. Memastikan kompetensi analis } \\
\text { dalam melakukan pemipetan. } \\
\text { 2. Membuat logbook pembuatan } \\
\text { standar untuk memastikan volume } \\
\text { pemipetan }\end{array}$ \\
\hline
\end{tabular}




\begin{tabular}{|c|c|c|c|c|}
\hline No. & Proses & Sumber kegagalan & $\begin{array}{l}\text { Potensi mode } \\
\text { kegagalan }\end{array}$ & usulan perbaikan \\
\hline 2 & $\begin{array}{l}\text { Pengukuran } \\
\text { dengan } \\
\text { menggunakan } \\
\text { ICP-MS }\end{array}$ & $\begin{array}{l}\text { Melakukan } \\
\text { pengecekan kondisi } \\
\text { instrument }\end{array}$ & $\begin{array}{l}\text { Analis tidak } \\
\text { melakukan } \\
\text { pengecekan kondisi } \\
\text { instrumen dengan } \\
\text { benar }\end{array}$ & $\begin{array}{l}\text { 1. Memastikan kompetensi analis. } \\
\text { 2. Membuat IK untuk pengecekan } \\
\text { kondisi instrumen } \\
\text { 3. Membuat logbook untuk } \\
\text { pengecekan kondisi instrumen } \\
\text { 4. Kontrol dari senior analis }\end{array}$ \\
\hline 3 & $\begin{array}{l}\text { Interpretasi } \\
\text { hasil }\end{array}$ & $\begin{array}{l}\text { Pengecekan kurva } \\
\text { kalibrasi }\end{array}$ & $\begin{array}{l}\text { Adanya konsentrasi } \\
\text { larutan contoh uji } \\
\text { yang diluar rentang } \\
\text { kurva kalibrasi }\end{array}$ & $\begin{array}{l}\text { 1. Penggunaan hasil screening XRF } \\
\text { untuk menentukan perkiraan } \\
\text { pengenceran larutan contoh uji. } \\
\text { 2. Pelatihan analis untuk perhitungan } \\
\text { perkiraan pengenceran. }\end{array}$ \\
\hline
\end{tabular}

Penulis selama Februari dan Maret 2020 mengambil data dari jumlah sampel uji logam berat yang dilakukan dan pengujian ulang yang terjadi untuk parameter uji ini. Dari data ini, persentase hasil pengujian ulang yang diperoleh dari total pengujian adalah $1,02 \%$. Berikut ini adalah data pengujian untuk Februari dan Maret 2020 setelah tindakan korektif diambil.

Tabel 4. Total Pengujian dan Pengujian Ulang Heavy Metal

\begin{tabular}{|l|r|r|r|}
\hline \multirow{2}{*}{ Heavy metal } & \multicolumn{2}{|c|}{ Bulan (2020) } & \multirow{2}{*}{} \\
\cline { 2 - 3 } & Februari & \multicolumn{1}{c|}{ Maret } & \multicolumn{1}{c|}{ Total } \\
\hline Pengujian & 1823 & 1799 & 3622 \\
\hline Pengujian ulang & 17 & 20 & 37 \\
\hline
\end{tabular}

Beberapa studi dari jurnal sebelumnya, seperti hasil penelitian Jiang, et.al, menyatakan bahwa tidak ada mode kegagalan risiko tinggi ( $R P N \geq 200)$ yang diidentifikasi dalam fase analisis laboratorium. Ini terjadi karena kontrol ketat telah dilakukan dan prosedur operasional telah dilaksanakan untuk mengurangi terjadinya kesalahan [12]. Van Leuween, et. Al. mengatakan dalam makalah mereka bahwa mode kegagalan tertinggi dalam analisis kimia adalah kurangnya kompetensi analis. Dengan demikian, disimpulkan secara luas bahwa faktor manusia adalah faktor paling penting dalam pengujian kimia [15]. Dalam penelitian ini, penyebab utama yang ditemukan adalah kurangnya kompetensi analis dan tidak ada prosedur operasional untuk beberapa langkah proses. 


\section{Kesimpulan}

Tujuan dari penelitian ini adalah untuk mengusulkan perbaikan dalam proses pengujian untuk mengurangi jumlah sampel pengujian ulang di laboratorium. Dengan menggunakan diagram Pareto, sumber kesalahan utama ditentukan, termasuk: Persiapan Sampel Uji, Pengukuran instrumen instrumen, dan nilai Uji di luar rentang kurva kalibrasi. Dengan menggunakan metode FMEA, akar utama masalah ditentukan dari kurangnya kompetensi personel, kurangnya pengendalian dari atasan dan ada beberapa prosedur operasional yang belum dibuat. Dari hasil perbaikan, data yang diambil pada bulan Februari - Maret 2020 menunjukkan ada penurunan persentase pengujian ulang untuk pengujian heavy metal dari $5.72 \%$ sebelum dilakukan perbaikan menjadi $1.02 \%$ setelah dilakukan perbaikan.

\section{Daftar Pustaka}

[1] B. G. Hwang, S. R. Thomas, C. T. Haas, and C. H. Caldas, "Measuring the impact of rework on construction cost performance," J. Constr. Eng. Manag., 2009.

[2] G. Lippi et al., "Effectiveness of a computerized alert system based on re-testing intervals for limiting the inappropriateness of laboratory test requests," Clin. Biochem., 2015.

[3] R. C. Hawkins, "Potentially inappropriate repeat laboratory testing in inpatients [16]," Clinical Chemistry. 2006.

[4] A. P. Huissoon and S. A. Carlton, "Unnecessary repeat requesting of tests in a university teaching hospital immunology laboratory: An audit [2]," Journal of Clinical Pathology. 2002.

[5] P. Carrano and M. Plebani, "Process control reduces the laboratory turnaround time [2]," Clinical Chemistry and Laboratory Medicine. 2002.

[6] P. E. D. Love, D. J. Edwards, J. Smith, and D. H. T. Walker, "Divergence or congruence? A path model of rework for building and civil engineering projects," $J$. Perform. Constr. Facil., 2009.

[7] W. K. Chong and S. P. Low, "Assessment of defects at construction and occupancy stages," J. Perform. Constr. Facil., 2005.

[8] S. Woodhouse, B. Burney, and K. Coste, "To err is human: Improving patient safety through failure mode and effect analysis," Clinical Leadership and Management Review. 2004.

[9] H. Hasbullah, M. Kholil, and D. A. Santoso, "ANALISIS KEGAGALAN PROSES INSULASI PADA PRODUKSI AUTOMOTIVE WIRES (AW) DENGAN METODE FAILURE MODE AND EFFECT ANALYSIS (FMEA) PADA PT JLC," SINERGI, 2017.

[10] M. L. Chiozza and C. Ponzetti, "FMEA: A model for reducing medical errors," Clin. Chim. Acta, 2009.

[11] M. Capunzo, P. Cavallo, G. Boccia, L. Brunetti, and S. Pizzuti, "A FMEA clinical laboratory case study: How to 
make problems and improvements measurable," Clin. Leadersh. Manag. Rev., 2004.

[12] Y. Jiang, H. Jiang, S. Ding, and Q. Liu, "Application of failure mode and effects analysis in a clinical chemistry laboratory," Clin. Chim. Acta, 2015.

[13] G. P. Putra and H. H. Purba, "Failure mode and effect aanalysis on power plant boiler," J. Optim. Ind. Eng., 2018.
[14] R. Thakore, R. Dave, and T. Parsana, "A Case Study: A process FMEA Tool to Enhance Quality and Efficiency of Bearing Manufacturing Indudtry," Sch. J. Eng. Technol., 2015.

[15] J. F. van Leeuwen et al., "Risk analysis by FMEA as an element of analytical validation," J. Pharm. Biomed. Anal., 2009. 